\section{Cell Division of a Double Mutant of Escherichia coli Bearing Lesions of recA and Thermosensitive Division Deficiency}

\author{
Masatomo Fukasawa, Kazuo NagaI \\ and Gakuzo TAMURA
}

\section{Department of Agricultural Chemistry, University of Tokyo}

Received July 16, 1976

In some bacteria including Escherichia coli, ${ }^{1)}$ Salmonella typhimurium ${ }^{2>}$ and Caulobacter crescentus ${ }^{33}$ cell division has been shown to couple with chromosome replication. When DNA synthesis is disturbed by the addition of inhibitors or by deprivation of thymine from the medium of a thymine-requiring strain, cells stop dividing and form filaments.

In 1971, Inouye ${ }^{4)}$ reported that recA strain of $E$. coli still continue to divide even in the absence of DNA synthesis. Therefore, cell division in this mutant is uncoupled with chromosome replication. However, it is unknown whether this division, unlinked to DNA synthesis, is regulated or accomplished through a process similar to normal division.

On the other hand, there are several thermosensitive mutants of $E$. coli deficient in cell division. ${ }^{5)}$ One of them, ts $20,{ }^{\theta)}$ grows normally at $30^{\circ} \mathrm{C}$ and stops dividing immediately after a temperature shift to $42^{\circ} \mathrm{C}$. Macromolecular syntheses including DNA, RNA, and protein are grossly normal at restrictive temperature.

Therefore, a double mutant bearing both lesions of thermosensitivity and $\operatorname{rec} A$ was prepared, and the process of division was examined.

The division mutant $\mathrm{ts} 20\left(\mathrm{~F}^{-}\right.$thr leu trp his thi thy ara lac gal $x y l$ mtl str ${ }^{\tau}$ ) derived from $E$. coli K12 JE 1011 was mated with $E$, coli $\mathrm{K} 12 \mathrm{KL} 16-99$ (Hfr rel-1 thi recA), and $\mathrm{Thy}^{-} \mathrm{His}^{+}$colonies were isolated. From the recombinants, a strain tsR20 which is thermosensitive, labile to mitomycin $C$ and deficient in recombination ability was selected and used for further study.

Cells were cultured in an enriched $\mathrm{M} 9$ medium containing $5.8 \mathrm{~g}$ of $\mathrm{Na}_{2} \mathrm{HPO}_{4}, 3.0 \mathrm{~g}$ of $\mathrm{KH}_{2} \mathrm{PO}_{4}, 0.5 \mathrm{~g}$ of $\mathrm{NaCl}, 1.0 \mathrm{~g}$ of $\mathrm{NH}_{4} \mathrm{Cl}, 11 \mathrm{mg}$ of $\mathrm{CaCl}_{2}, 246 \mathrm{mg}$ of $\mathrm{MgSO}_{4} \cdot 7 \mathrm{H}_{2} \mathrm{O}, 4 \mathrm{~g}$ of glucose, $2 \mathrm{~g}$ of casamino acids, $20 \mathrm{mg}$ of tryptphan, $2 \mathrm{mg}$ of thiamine and $10 \mathrm{mg}$ of thymine per liter of distilled water. The cell number were assayed by a Coulter counter model $\mathrm{Zb}$ after the appropriate dilution of the culture with filtered saline.

As reported previously, ${ }^{\theta)}$ cells of ts 20 proliferated exponentially at $30^{\circ} \mathrm{C}$, and stopped dividing after a temperature shift to $42^{\circ} \mathrm{C}$. When the culture was shifted back from $42^{\circ}$ to $30^{\circ} \mathrm{C}$, the cell number increased more rapidly than the normal culture at $30^{\circ} \mathrm{C}$, indicating accumulation of division potential during incubation at restrictive temperature. No increase was observed when chloramphenicol (CP) was added at the time of the temperature was shift back. Similar results were obtained with tsR20.

When thymine was deprived from the medium, no increase in cell number was observed with ts 20 even at the permissive temperature. However, a recA derivative of ts 20 , tsR20 continued to divide in the absence of thymine, and the cell number increased linearly for three hours after the deprivation. This process of division, unlinked to DNA synthesis, was shown to be thermosensitive as well as the normal division. The cells formed filaments as long as those observed in the presence of thymine during incubation at $42^{\circ} \mathrm{C}$, as indicated by morphological examination and by increased absorbance.

The number of tsR 20 cells without thymine increased when the culture was shifted back from $42^{\circ}$ to $30^{\circ} \mathrm{C}$, and this division was also sensitive to $\mathrm{CP}$. However, in contrast to the case in the presence of thymine, no burst in cell division was observed. Therefore, no accumulation of division potential was shown during incubation

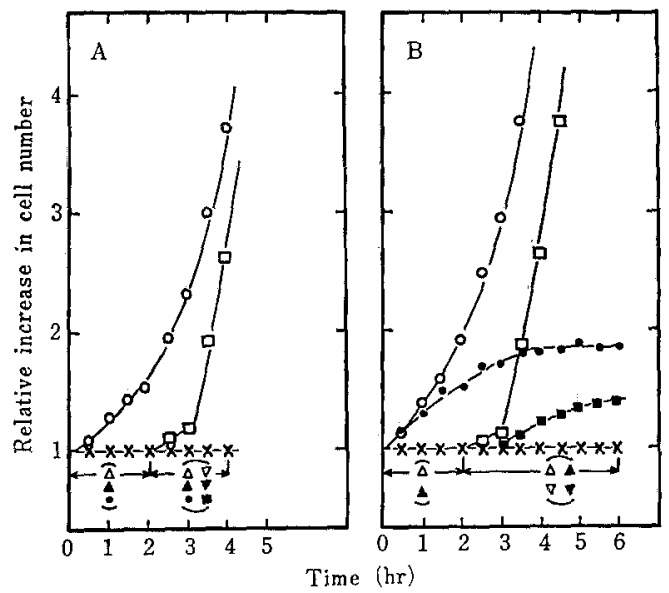

FIG. 1. Effect of Temperature and Thymine on Division of $t s 20$ (A) and tsR20 (B).

An exponentially growing culture in enriched M9 at $30^{\circ} \mathrm{C}$ was filtered and washed. Cells were resuspended in M9 medium supplemented with (open symbols) or without (closed symbols) thymine. Two parts of the culture were incubated at $30^{\circ} \mathrm{C}(\mathrm{O}$ and 9 ) and the other two parts were shifted to $42^{\circ} \mathrm{C}$ ( $\triangle$ and $\Delta$ ). After $120 \mathrm{~min}$ of incubation at $42^{\circ} \mathrm{C}$, fractions of the latter were shifted back to $30^{\circ} \mathrm{C}$ with $(\nabla$ and $\nabla$ ) or without ( $\square$ and $\square$ ) $100 \mu \mathrm{g} / \mathrm{ml}$ of CP. The mark (x) represents the positions of the samples in the parentheses as all these samples showed the same or very close values. 


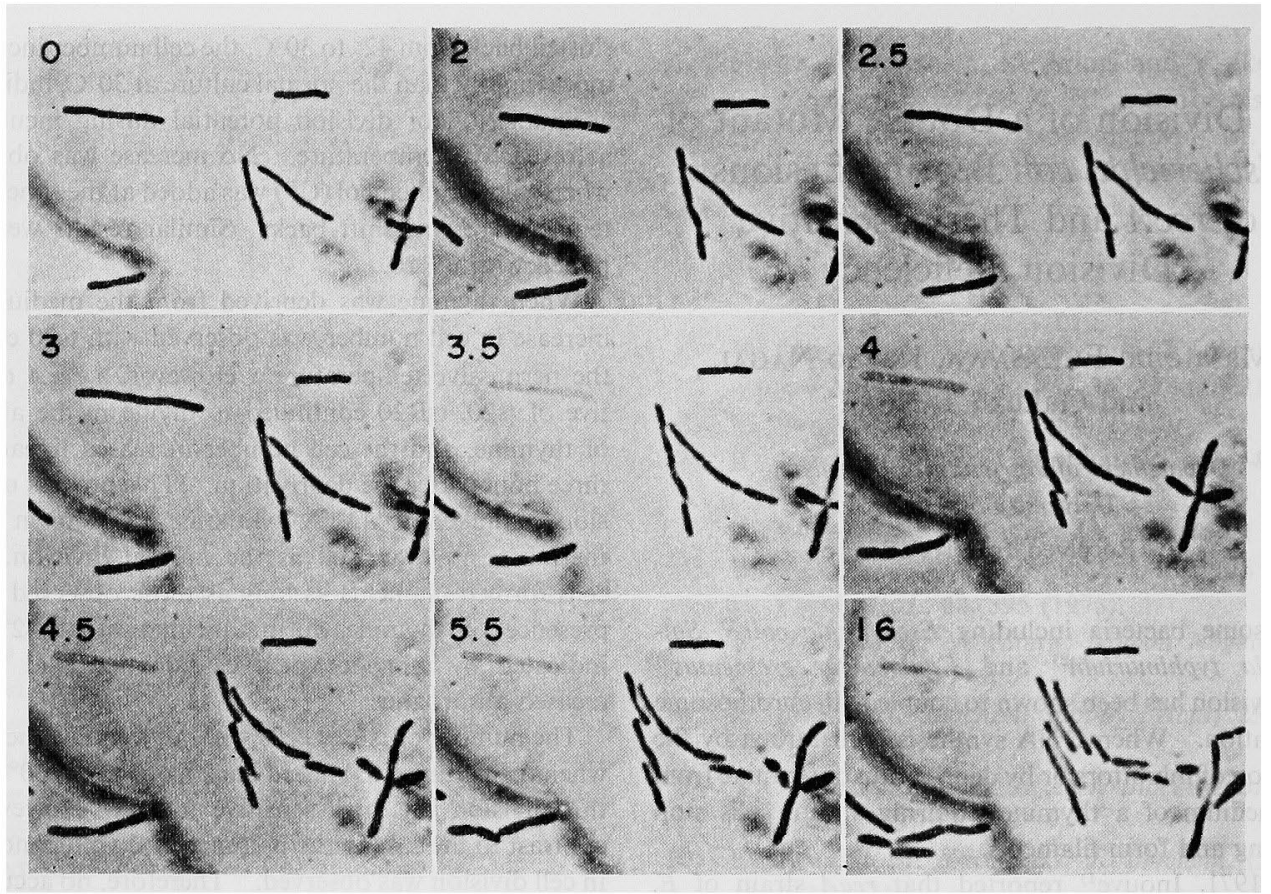

FIG. 2. Division of ts 20 Filaments at $20^{\circ} \mathrm{C}$.

After 120 min of incubation in thymine deficient $\mathrm{M} 9$ medium at $42^{\circ} \mathrm{C}$, the filaments of tsR 20 produced were placed on a glass slide precoated with thymine deficient $\mathrm{M} 9$ agar and cultivated at $20^{\circ} \mathrm{C}$ (time 0 ). The slide was examined by a phase-contrast microscope at $0.2,2.5,3,3.5,4,4.5,5.5$, and $16 \mathrm{hr}$ of incubation.

at $42^{\circ} \mathrm{C}$ when the culture was deprived of thymine. The results are presented in Fig. 1.

The filaments of tsR 20 produced by $120 \mathrm{~min}$ of incubation without thymine at $42^{\circ} \mathrm{C}$ were placed on a thymine omitted $\mathrm{M} 9$ agar-coated glass slide at $20^{\circ} \mathrm{C}$ and examined under a phase-contrast microscope at different time intervals. As shown in Fig. 2, many of the filaments divided once, twice or three times during $5.5 \mathrm{hr}$ of incubation. Cells which failed to divide or lyzed were also found in the same range of vision. Most cells elongated gradually during incubation. Contrary to ts $\mathrm{R} 20$, the parent strain ts 20 produced no new cells and only formed flaments longer than tsR20 under the same conditions of cultivation as above. The result coincided with that of total cell count.

From above results of double mutant ts 20 , the division of rec $A$ strain in the absence of DNA synthesis seemed to be accomplished through the process participating in normal division because (1) both divisions were thermosensitive and (2) both divisions after a temperature shift back from $42^{\circ}$ to $30^{\circ} \mathrm{C}$ were sensitive to CP. However, there was no accumulation of division potential when tsR20 was incubated at $42^{\circ} \mathrm{C}$ in the absence of thymine in contrast to the presence of thymine. This may suggest that normal synthesis of DNA is required to retain division activity during incubation at restrictive temperature.

Acknowledgment. This work was supported by a grant from The Ministry of Education, Science and Culture of Japan.

\section{REFERENCES}

1) D. J. Clark, J. Bacteriol., 96, 1214 (1968).

2) B. G. Spratt and R. J. Rowbury, J. Gen. Microbiol., 65, 305 (1971).

3) S. T. Degnen and A. Newton, J. Bacteriol., 110, 852 (1972).

4) M. Inouye, ibid., 106, 539 (1971).

5) M. Slater and M. Schaechter, Bacteriol. Rev., 38, 199 (1974).

6) K. Nagai and G. Tamura, J. Bacteriol., 112, 959 (1972) 